\title{
Drug use detection in medical occurrences involving physical trauma
}

\author{
Detecção de uso de drogas em ocorrências médicas envolvendo trauma físico \\ Detección del uso de drogas en ocurrencias médicas con trauma físico
}

\author{
Marcelo da Silva \\ ORCID: https://orcid.org/0000-0002-0376-0430 \\ State University of Maringa, Brazil \\ E-mail: marceloassencio@hotmail.com \\ Deborah Thais Palma Scanferla \\ ORCID: https://orcid.org/0000-0001-7715-724X \\ State University of Maringa, Brazil \\ E-mail: deborahscanferla@gmail.com \\ Érika Bando \\ ORCID: https://orcid.org/0000-0002-5828-8073 \\ State University of Maringa, Brazil \\ E-mail: ebando@gmail.com \\ Simone Aparecida Galerani Mossini \\ ORCID: https://orcid.org/0000-0001-9535-0983 \\ State University of Maringa, Brazil \\ E-mail: sagmossini@uem.br \\ Magda Lúcia Félix de Oliveira \\ ORCID: https://orcid.org /0000-0003-4095-9382 \\ State University of Maringa, Brazil \\ E-mail: mlfoliveira@uem.br
}

\begin{abstract}
Objetive: to evaluate the use drugs by individuals hospitalized due to non-lethal physical trauma. Methods: prospective study carried out on a transversal cohort by assessing secondary data and toxicological analyses in a hospital of a municipality of Southern Brazil. Individuals were selected after being hospitalized due to trauma likely to be caused by drug abuse. There were assessing cases reported by public and private basic health care systems registered by the Center for Control of Intoxications, which were identified by clinical criteria or due to reports from the subjects. Biological samples were obteined for toxicological trialing. Results: nine cases $(17.7 \%)$ were consideraded moderate or severe by the Glasgow trauma scale, and results obtained using the Revisited Trauma Score system indicated three cases (6.7\%) as oderate or severe. The most severe cases involved individuals aged 20 to 39 . Quantitative analysis $\mathrm{f}$ ethanol determined its presence in all samples, and at toxic levels in $15.8 \%$ of the biological amples assessed. Nine subjects had used cannabis $(15.8 \%)$ and five had used cocaine (8.8\%) in association with ethanol. Conclusion: the high incidence of drug use in the assessed subjects confirms the relation between drug abuse and increased risk for physical traumas.
\end{abstract}

Keywords: Injuries; Accidents; Violence; Trauma; Illicit Drugs.

\section{Resumo}

Objetivo: Avaliar o uso de drogas por indivíduos hospitalizados por trauma físico não letal. Metodologia: Estudo prospectivo realizado em coorte transversal, com análise de dados secundários e análises toxicológicas em hospital de um município do Sul do Brasil. Os indivíduos foram selecionados após internação hospitalar em decorrência de traumas com provável associação ao uso abusivo de drogas. Foram avaliados casos originados dos serviços de atenção pré-hospitalar públicos e privados cadastrados no Centro de Controle de Intoxicações, identificados por critérios clínicos ou por relato dos sujeitos. Amostras biológicas foram obtidas para testes toxicológicos. Resultados: Nove casos $(17,7 \%)$ foram considerados moderados ou graves pela escala de trauma de Glasgow. Os resultados obtidos pelo sistema Revisited Trauma Score indicaram três casos $(6,7 \%)$ como moderados ou graves. Os casos mais graves envolveram indivíduos de 20 a 39 anos. A análise quantitativa do etanol em sangue determinou sua presença em todas as amostras e em níveis tóxicos em 15,8\% das amostras biológicas avaliadas. Nove indivíduos usaram cannabis $(15,8 \%)$ e cinco usaram cocaína $(8,8 \%)$ associada ao etanol. Conclusão: A alta incidência de uso de drogas nos sujeitos avaliados confirma a relação entre o uso abusivo de drogas e o aumento do risco para traumas físicos.

Palavras-chave: Lesões; Acidentes; Violência; Trauma; Drogas de abuso.

\section{Resumen}

Objetivo: Evaluar el uso de drogas por parte de personas hospitalizadas por trauma físico no letal. Metodología: Estudio prospectivo realizado en una cohorte transversal, con análisis de datos secundarios y análisis toxicológicos en 
un hospital de un municipio del sur de Brasil. Los individuos fueron seleccionados después de la hospitalización por trauma con probable asociación con abuso de drogas. Se evaluaron los casos provenientes de los servicios de atención prehospitalaria públicos y privados registrados en el Centro de Toxicología, identificados por criterios clínicos o por informes de los sujetos. Se obtuvieron muestras biológicas para pruebas toxicológicas. Resultados: Nueve casos $(17,7 \%)$ fueron considerados moderados o graves por la escala de trauma de Glasgow. Los resultados obtenidos por el sistema Revisited Trauma Score indicaron tres casos $(6,7 \%)$ como moderados o graves. Los casos más graves afectaron a personas de 20 a 39 años. El análisis cuantitativo de etanol en sangre determinó su presencia en todas las muestras y a niveles tóxicos en el 15,8\% de las muestras biológicas evaluadas. Nueve personas consumieron cannabis $(15,8 \%)$ y cinco consumieron cocaína $(8,8 \%)$ asociada con etanol. Conclusión: La alta incidencia de uso de drogas en los sujetos evaluados confirma la relación entre el abuso de drogas y el aumento del riesgo de trauma físico.

Palabras clave: Lesiones; Accidentes; Violencia; Trauma; Drogas de uso indebido.

\section{Introduction}

Although drug abuse is a growing public health problem, epidemiological surveillance to detect and evaluate drug abuse is recent. Major issues faced by public health organizations when making decisions and taking actions that concern drug abuse are often linked to insufficient data that impairs proper assessment of drug abuse in society (Silva et al., 2016; Macinko, 2015; Oliveira \& Cruz, 2015).

Monitoring drug abuse is crucial to support public policies and implement prevention programs. However, drug abuse is often considered little influenced by the intervention of health services, as it is closely linked to other social factors. Thus, surveillance systems aimed at monitoring key indicators in the general population or specific groups can be valuable for alerting public health agencies and promoting the implementation of good quality policies (Santana et al., 2020; Rutstein et al., 1976; Ministério da Saúde, Brasil [MS], 2019).

Drug users usually seek health services when they suffer from complications due to compulsive and chronic use and in circumstances when there are violence and trauma involved. Monitoring when drug users seek health services is essential to carry out policies linked to health surveillance (Okumura et al., 2012; Rutstein et al., 1976). Knowing the events that lead to drug use allows for timely interventions that should prevent physical traumas and hospitalization caused by abuse (Degenhardt, Mathers \& Hall, 2014; Martins, 2013).

There is a scarcity of epidemiological data on drugs commonly consumed in physical trauma episodes or there are several biases in the available data and there are gaps in the consequences related to drugs and the occurrence of traumas and deaths (Andrecceutti et al., 2018).

Although the systematic data collection on substance use in cases of fatal injuries is encouraged by international organizations. United Nations Office on Drugs and Crime [UNODC] (2019); World Health Organization [WHO] (2018a), there is insufficient data on non-fatal trauma and little has been done to understand the complex "scenario of drug use and its connection with injuries". In low- and middle-income countries, little is known about the use of alcohol and other drugs among patients who had physical trauma, although the World Health Organization (WHO) estimates that $90 \%$ of injury-related deaths worldwide take place in these countries (Mundenga et al, 2019; World Health Organization [WHO] (2009).

Thus, it is essential to collect data on substance use among victims of physical trauma, especially in the Latin American region, where both traffic accidents and interpersonal violence have taken epidemic proportions in recent years (Andrecceutti et al., 2018; (WHO, 2018a)). Within this context, we aimed to report data on the use of alcohol and other drugs associated with events of non-fatal physical injuries in hospitalized individuals, included as surveillance in a drug abuse monitoring program.

\section{Methodology}

This is a retrospective transversal cohort study, with a qualitative and quantitative approach. This study followed the methodological recommendations described by Pereira et al (2018). Results were obtained from secondary data and 
toxicological analyzes. The study took place in a hospital of a municipality of Southern Brazil, using data from the Toxicology Assistance Control Center.

The assessed population was composed of 57 individuals which had suffered non-lethal trauma associated (or the probable association) with drugs, as determined by clinical assessment or self-reported by the subjects at the moment of admission. Data from a period comprising eight months in 2016 were used in this study. Subjects were included in the study by order of admission in the hospital according to notification of the case as a surveillance-related event in a program of local monitoring of drug abuse intoxication (Santana et al., 2014).

All data were organized using the software Microsoft Office Excel 10.0 and descriptive data analysis was performed (measures of central location and dispersion). For determination injury severity, the Glasgow Coma Scale - GCS and the Revisited Trauma Score - RTS were used (Champion et al., 1981; Teasdale \& Jennett, 1974).

Screening tests were carried out by immunochromatography using urine as samples to analyze cocaine and cannabis (RapidTox® America Biomedica). To quantify the alcohol, plasma samples were assessed using a Vitros Analyzer 250® (Johnson \& Johnson Company).

Table 1 shows the association between alcohol blood levels and commonly related signs and symptoms. Even when presenting the same concentration of alcohol individuals can be classified at different stages of intoxication due to the sensitivity to alcohol, which varies greatly among individuals (Levine, 1999, pp. 170-184). Clinically, blood alcohol concentrations superior to $10 \mathrm{mg} / \mathrm{dL}$ (1dg/L) characterize mild effects; concentrations ranging from 30 to $90 \mathrm{mg} / \mathrm{dL}$ (3 to 9 $\mathrm{dg} / \mathrm{L}$ ) are characterized by euphoria and reduced awareness and rational abilities; concentrations ranging from 90 to $180 \mathrm{mg} / \mathrm{dL}$ ( 9 to $19 \mathrm{dg} / \mathrm{L}$ ) are characterized by excitement and absence of rational abilities; and concentrations ranging from 180 to 300 $\mathrm{mg} / \mathrm{dL}$ (10 to $30 \mathrm{dg} / \mathrm{L}$ ) are characterized by unawareness, mental confusion, loss of balance and perception (Passagli, 2018).

Table 1: Correlation between alcohol blood levels and clinical effects.

\begin{tabular}{|c|c|c|}
\hline $\begin{array}{l}\text { Alcohol blood } \\
\text { levels (g/L) }\end{array}$ & Overall condition & Clinical signs and symptoms \\
\hline 0.1 to 0.5 & Subclinical & Mild subclinical effects \\
\hline 0.3 to 1.1 & Euphoria & $\begin{array}{l}\text { Minor euphoria, increased sociability, decreased inhibition, } \\
\text { reduced attention, and self-control. }\end{array}$ \\
\hline 0.9 to 2.5 & Excitement & $\begin{array}{l}\text { Emotional instability, absence of rational abilities, memory loss, } \\
\text { reduced perception. }\end{array}$ \\
\hline 1.8 to 3.0 & Confusion & $\begin{array}{l}\text { Disorientation, mental confusion, vertigo, exaggerated emotions, } \\
\text { reduced perception, loss of balance, reduced ability to walk and } \\
\text { impaired speech. }\end{array}$ \\
\hline 2.5 to 4.0 & Stupor & $\begin{array}{l}\text { Apathy, inertia, reduced response to any stimuli, inability to walk } \\
\text { and communicate, vomiting, incontinence, unconsciousness. }\end{array}$ \\
\hline 3.5 to 5.0 & Coma & No reflexes, coma, anesthesia, impaired breathing. \\
\hline Above 4.5 & Death & Respiratory failure. \\
\hline
\end{tabular}

Source: Levine (1999); cited by Passagli (2018). 
The study was approved by the Ethics Committee for Research on Human Beings from the institution and approved under CAAE number 06218713.0.0000.0104, under favorable opinion number 458,185. All samples collected from individuals were labeled using laboratory codes, thus preserving the confidentiality of the research subjects.

\section{Results}

From the assessed subjects, most were male (55-96.5\%), aged from 16 to 84 (mean of 41). Upon hospital admission, 7 individuals (9.9\%) reported signs and symptoms related to polytraumas, but most of the injuries found in this study involved contusions, fractures, and excoriations. Neurological alterations such as psychomotor agitation, aggressive behavior, drowsiness/torpor, convulsions, mental confusion, and tremor were also identified. The hospitalizations assessed in this study lasted for a mean of 5 days; one person died due to polytrauma aggravated by firearm injuries.

Table 2 shows the circumstances associated with the episode that led to trauma-related with alcohol levels. Most traumas were caused by road accidents $(29-50.9 \%)$, especially motor vehicle crash and bicycle accidents, and by falls $(15-$ 26.3\%). Two of the assessed cases of road accidents were considered severe. Most incidents happened at night (7 - 77.7\%) (from 06:00 PM to 06:00 AM), especially at late hours of the night, when people are more likely to socialize and drink alcoholic beverages and use other drugs. However, there were no peak times for the incidents to happen. Falling on same level, a major cause for trauma reported in this study, is when an individual falls from a higher to a lower level, which causes injuries when reaching the ground.

Table 2: Characteristics of trauma events associated with alcohol. January to August 2016.

\begin{tabular}{|c|c|c|c|c|c|c|}
\hline $\mathbf{N}$ & $\begin{array}{c}\text { Ethanol } \\
\text { blood levels }\end{array}$ & $\begin{array}{c}\text { Age } \\
\text { (years) }\end{array}$ & Type of occurrence & $\begin{array}{c}\text { Time } \\
\text { (Hours) }\end{array}$ & GCS* & RTS** \\
\hline 1 & $136 \mathrm{mg} / \mathrm{dL}$ & 45 & Fall on same level & 08:59 am & 11 & 12 \\
\hline 2 & $174 \mathrm{mg} / \mathrm{dL}$ & 50 & Fall on same level & 01:14 am & 15 & 12 \\
\hline 3 & $230 \mathrm{mg} / \mathrm{dL}$ & 61 & Fall from bicycle & 01:44 pm & 15 & 12 \\
\hline 4 & $10 \mathrm{mg} / \mathrm{dL}$ & 45 & Physical aggression & $02: 36 \mathrm{am}$ & 15 & 12 \\
\hline 5 & $108 \mathrm{mg} / \mathrm{dL}$ & 53 & Fall from bicycle & 06:06 am & 11 & 12 \\
\hline 6 & $105 \mathrm{mg} / \mathrm{dL}$ & 38 & Motor-vehicle collision & $11: 17$ am & 3 & -- \\
\hline 7 & $115 \mathrm{mg} / \mathrm{dL}$ & 84 & Fall on same level & 07:37 am & 15 & -- \\
\hline 8 & $37 \mathrm{mg} / \mathrm{dL}$ & 20 & Motor-vehicle collision & 09:37 am & 15 & 12 \\
\hline 9 & $133 \mathrm{mg} / \mathrm{dL}$ & 22 & Physical aggression & $12: 16 \mathrm{am}$ & 3 & 3 \\
\hline
\end{tabular}

Source: the authors. *Glasgow coma scale. ** Revisited Trauma Score.

For all cases, alcohol was the most reported drug consumed in the last six hours before hospital admission. Alcohol breath could be detected in 43 individuals (75.4\%). Most reported a long-term use of alcohol (47-66.2\%). 
It is noteworthy, however, that the alcohol drinker, especially a binge drinker, presents signs and symptoms easily detected in physical examination, such as alcoholic breath, which was found in $75.4 \%$ of the present sample. The fact that alcohol is a "legal" drug, makes the patient confident to report abuse when he gets to the hospital.

Table 3 shows the blood alcohol levels used as a reference in this study, based on the classification suggested by Levine (1999, pp. 170-184). Most cases involved alcohol at lower concentrations, which lead to mild subclinical conditions, but there was a high number of cases involving alcohol at high concentrations that caused disorientation, mental confusion, exaggerated emotions, alterations of perception, lack of muscle coordination and impairment of speech and walking (Passagli, 2018).

Table 3: Alcohol blood levels and correlation with toxic effects in individuals hospitalized due to trauma. January to August 2016.

\begin{tabular}{cccc}
\hline Blood levels & Toxic effect & $\mathbf{N}$ & $\mathbf{\%}$ \\
$4-10 \mathrm{mg} / \mathrm{dL}$ & Subclinical & 48 & 84.2 \\
$11-100 \mathrm{mg} / \mathrm{dL}$ & Euphoria, & 2 & 3.50 \\
& Excitment & & \\
$>100 \mathrm{mg} / \mathrm{dL}$ & Confusion, Stupor & 7 & 12.3 \\
Total & & $\mathbf{5 7}$ & $\mathbf{1 0 0}$ \\
\hline
\end{tabular}

Source: Authors.

A total of 57 samples, obtained from the assessed subjects, were tested (Table 4) and cannabis could be detected as frequently as alcohol at toxic levels.

Table 4: Results for toxicological analysis (cocaine and cannabis) and assessment of alcohol blood levels. January to August 2016.

\begin{tabular}{lccc}
\hline \multirow{3}{*}{ Alcohol } & Drug of abuse & N & \% \\
& & & \\
& $4-10 \mathrm{mg} / \mathrm{dL}$ & 48 & 84.2 \\
Cannabis & $>10 \mathrm{mg} / \mathrm{dL}$ & 9 & 15.8 \\
& & & \\
& Positive & 9 & 15.8 \\
Cocaine & Negative & 48 & 84.2 \\
& & & \\
& Positive & 5 & 8.8 \\
Total & Negative & 52 & 91.2 \\
\hline
\end{tabular}

Source: Authors. 
Table 5 shows the correlation between cannabis detected in urine (qualitative analysis) and some aspects associated with the occurrence that caused the individual's hospitalization. Glasgow and RTS scales showed two cases as severe; they were associated with traffic collisions and physical aggression.

Table 5: Characteristics of trauma events associated with cannabis and cocaine. January to August 2016.

\begin{tabular}{|c|c|c|c|c|c|c|}
\hline $\mathbf{N}$ & $\begin{array}{c}\text { Age } \\
\text { (years) }\end{array}$ & Drug use & Type of occurrence & $\begin{array}{c}\text { Time } \\
\text { (Hours) }\end{array}$ & GCS* & RTS** \\
\hline 1 & 36 & cannabis & Physical aggression & 01:09am & 15 & 12 \\
\hline 2 & 27 & cannabis & Fall from bicycle & 05:12am & -- & -- \\
\hline 3 & 38 & cannabis & Motor-vehicle collision & $11: 17 \mathrm{pm}$ & 3 & -- \\
\hline 4 & 48 & cannabis & Fall from motorcycle & $04: 33 \mathrm{pm}$ & -- & -- \\
\hline 5 & 18 & cannabis & Motor-vehicle collision & 02:16am & 14 & 12 \\
\hline 6 & 22 & cannabis & Physical aggression & $12: 16 a m$ & 3 & 3 \\
\hline 7 & 42 & cannabis & Fall from motorcycle & 08:30pm & 15 & 12 \\
\hline 8 & 16 & cannabis & Firearm Injury & 03:30pm & 15 & 12 \\
\hline 9 & 17 & cannabis & White Gun Injury & 03:38am & -- & -- \\
\hline 10 & 21 & cocaine & Motor-vehicle collision & 00:38am & 12 & 12 \\
\hline 11 & 25 & cocaine & Fallfrommotorcycle & $05: 53 \mathrm{pm}$ & 15 & 12 \\
\hline 12 & 20 & cocaine & Motor-vehicle collision & $09: 37 \mathrm{pm}$ & 15 & 12 \\
\hline 13 & 25 & cocaine & Vehicle overturning & 00:51am & 15 & 12 \\
\hline 14 & 17 & cocaine & White Gun Injury & 03:38am & -- & -- \\
\hline
\end{tabular}

Source: Authors.

*Glasgow coma scale. ** Revisited Trauma Score.

Table 5 also shows the correlation between cocaine detected in urine (qualitative analysis) and some aspects associated with the occurrence that caused the individual's hospitalization. Most cases involved young individuals, with a mean age of 21.6, and generally involved road accidents.

\section{Discussion}

The prevalence of male at working-age subjects involved with injuries and poisoning is corroborated by other studies that report on the characteristics of hospitalizations due to external causes in Brazil, that also revealed a greater number of hospitalizations of male subjects at the same characteristics (Bastos et al., 2017; Damacena et al., 2016; Malta et al., 2015). Both classic and recent studies found in scientific literature report males are more subjected to trauma and injuries, mostly due to work-related practices and also because men are more likely to act impulsive and to neglect risk behaviors (Damacena et al., 2016; Souto, Corassa, Lima \& Malta, 2017). 
The signs and symptoms related to polytraumas findings are consistent with data from other studies carried out in reference hospitals, where mild traumas are most frequent (70-75\% of cases), followed by moderate (10-15\% of cases) and severe traumas (10-15\% of cases) (Andreuccetti et al., 2017; Gomes et al., 2016).

Polytrauma, in which there is an injury in more than one area of the body, is usually linked to road accidents, falls or major aggressions, and usually points little chances of survival. (Waksman \& Imamura, 2013).

In Brazil, traumas are among the most common causes of morbidity and mortality, surpassed only by cardiovascular diseases. However, there is no integrated information system that allows identification of all accidents, regardless of their severity and the time when these individuals seek health services because of them, which makes data collected at the moment of hospitalization crucial for acknowledging the problem (Brandão et al., 2014).

While mortality is certainly the most important complication from accidents, trauma can lead to permanent consequences for the individuals involved, such as physical incapacities, along with the burdening of health care services (Macinko, 2015; Andreuccetti et al., 2017; Organização Pan-Americana de Saúde [OPAS], 2018).

The prevalence of traumas caused by road accidents and by falls related in our study were often reported by emergency services, representing greater frequency of all of all accidents that led people to such services (Parreira et al., 2014; Andrade, 2012).

The detection of alcohol consumed in the last six hours before most injuries suggests a correlation with the effects of alcohol on the human organism, especially on the central nervous system (CNS). This system is quickly affected by alcohol intake, which leads to depression. Blood levels of alcohol depend on the consumed dose, speed of absorption by the gastrointestinal system and ability of the body to eliminate the substance through biotransformation and excretion processes (Brunton, Lazo \& Parker, 2018; Moreau \& Siqueira, 2016).

At small doses, the ingestion of alcoholic beverages causes euphoria. However, high blood alcohol concentrations can impair attention and peripheral sight, increase reaction time, causes drowsiness and cause neuromotor changes. This makes alcohol an aggravating factor for death among victims of traffic accidents (OPAS, 2018; WHO, 2018a; Damacena et al., 2016; Macinko et al., 2015).

Alcoholic beverages are freely commercialized and are relatively inexpensive when compared to other psychoactive substances. Because it is easy to acquire, it is common for individuals to engage in binge drinking, where high doses are consumed quickly on single occasions, promoting high-risk behavior World Health Organization [WHO] (2018b).

Blood alcohol levels correlate well with clinical signs and symptoms and can be used for interpretation of clinical cases. The alcohol has central nervous effects, such as loss of psychomotor abilities which compromises the reflexes and the capability of safe driving (Klassen, 2016; Moreau \& Siqueira, 2016). The detection of cannabis associated with alcohol need to be better explored. In a study carried out in Brazilian capitals with more than 200.000 inhabitants, it was found that $21,6 \%$ of assessed individuals used drugs (not including alcohol and tobacco), being cannabis the most commonly consumed (Bastos et al., 2017). THC, the most biologically active of the cannabinoids, is quickly absorbed and distributed to the CNS and other organs where it causes relaxation and feelings of well-being followed by enhanced sensorial perception, similar to the effects caused by alcohol, but not leading to aggressive-behavior (Passagli, 2018).

In the last years, research has advanced and now can better detail unknown properties of cannabis and its mechanism of action. The finding of endocannabinoids in the human body and the mapping of cannabinoid receptors allowed a better understanding of the chronic and therapeutic effects of cannabis (Moreau \& Siqueira, 2016). However, when smoked, cannabis causes effects similar to those caused by alcohol ingestion except for the aggressive behavior, and it improves perception; at elevated doses, cannabis can induce anxiety, confusion, paranoia and toxic psychosis (Brunton et al., 2018; Di Marzo, Bifulco \&Petrocellis, 2014). Effects from smoking cannabis begin after 0-10 minutes and peak at after 30 minutes; 
after 45-60 minutes, the effects start to disappear. The main subjective effects are the sensation of feeling well and calm), increased perception and sensations similar to hallucinations. The peripheral effects include tachycardia, vasodilation (accentuated in the sclera and conjunctiva vessels), an increase in intraocular pressure and bronchodilation. At high doses, cannabis-leads to anxiety, confusion, paranoia, aggressive behavior, and toxic psychosis (Brunton et al., 2018).

The alcohol use associated with cocaine is known and also worrisome. The combined use of them mixes mechanisms of toxicity: cocaine metabolism is inhibited by alcohol, cocaethylene is formed as a secondary metabolite, and the toxic effects of cocaine become more potent. Cocaine and alcohol are entertaining drugs which, separately, increase the release of dopamine in the nucleus accumbens, which leads to euphoria. Due to the synergistic effects of cocaine and alcohol, it is common that the simultaneous use of these drugs increases morbidity and mortality (Passagli, 2018).

The association of alcohol and others drugs use and accidents was observed in brazilian and worldwide studies (Mundenga et al, 2019; Andrecceutti et al., 2018; Bakke, Normann, Ekeberg \& Bachs, 2016; Lasebikan \& Adebayo, 2013; Legrand, Silverans, Paepe, Buylaert \& Verstraete, 2013), which corroborate to those found in this study.

The influence of drugs has been considered one of the main risk factors for the occurrence of accidents as it affects the reflexes and increases risky choices, such as interpersonal violence and transgression of traffic legislation (Souto et al., 2020; OPAS, 2018; Malta et al., 2015). The important number of drug-related use among victims of trauma injuries requires further studies that focus on intervention programs and that emphasize the planning of actions based on the local reality.

In many cases, the occurrence of polydrug use makes hard to determine how specific drugs affect the reflexes. It is difficult to know which drug had the greater effect. But, it is well known that many crashes are caused by drugged driving. Goods and low costs roadside test for drug levels in the body are still in test. Added to that, drugs can stay in our system for days or weeks after use, making it difficult to determine when the drug was used, and therefore, how and if it impaired driving (Hartman et al., 2015; Elvik, 2013; National Institute on Drug Abuse [NIDA], 2019).

While many studies worldwide use the patient's verbal report or a screening tool to detect the use of alcohol and illicit drugs in patients with physical trauma, our study and other studies have shown that the analytical toxicological test is more accurate and provides the evidence for psychoactive substances abuse, allowing information when patients are unable to do so and avoiding an incorrect estimate of drug and alcohol use. However, one of the main limitations of using toxicological tests is their high cost, a reality in most low- and middle-income countries (Mundenga et al., 2019; UNODC, 2019; WHO, 2018b).

As limitations of this study are the challenge to work with secondary data giving them the right quality, the intentional sampling process, and the possibility of false-positive results in toxicological screening, due to inherent factors of the method or individual characteristics. However, it is emphasized that data from surveillance programs and information of toxicology assistance centers, which are considered surveillance units that combines and captures social problems of toxicological events, which represent an important source for assessing the reality of accidents that involve drugs. Also, we can mention as limitations of this study, the fact that it was carried out in a hospital of a small municipality. Thus, the results may not be generalized to other regions of Brazil. Toxicological tests were used only for alcohol, cannabis, and cocaine, so we may have missed other illicit drugs that were not included in our drug screening.

\section{Conclusion}

Our findings show blood levels of alcohol and illicit drugs in urine were assessed in subjects found to be more frequent in young and male. Most episodes involving hospitalizations happened in the nighttime. All the factors together increase the chance of road accidents and aggressive behavior, favoring trauma injuries. 
The results pointed to an association between the use of cannabis and cocaine with events leading to physical trauma, which is a scarcely discussed theme in the scientific literature. The results also showed alcohol is often combined with the use of other illicit drugs in all assessed cases.

The assessed cases in the present study provide important data for epidemiological analyzes, as they demonstrate that trauma leading to hospitalization can be easily related to drug abuse. Therefore, health surveillance systems and toxicological testing allow for the establishment of better public health policies aimed at preventing the abuse of alcohol and other illicit drugs.

Interventions could focus on alcohol and illict drug use patients, however, interventions for illicit drug use, in combination with alcohol, should be further developed. As a perspective for future work, we intend to implement active methods of epidemiological surveillance, events and sentinel units, that can be used in the formulation of indicators for monitoring care and implementing local public policies.

\section{Acknowledgments}

To Decit/SCTIE/MS; CNPq; Fundação Araucaria and SESA-PR for the support and financing of the project. We are thankful to Conselho Nacional de Desenvolvimento Científico e Tecnológico (CNPq) and Coordenação de Aperfeiçoamento de Pessoal de Nível Superior (CAPES) for their financial support.

\section{References}

Andrade, S. S. C. A., Sá, N. N. B., Carvalho, M. G. O., Lima, C. M., Silva, M. M. A., Moraes Neto, O. L. \& Malta, D. C. (2012). Perfil das vítimas de violências e acidentes atendidas em serviços de urgência e emergência selecionados em capitais brasileiras: Vigilância de Violências e Acidentes, 2009. Epidemiologia e Serviços de Saúde, 21(1), 21-30.

Andreuccetti, G., Cherpitel, C. J., Carvalho, H. B., Leyton, V., Miziara, I. D., Munoz, D. R., \& ... Lemos, N. P. (2018). Alcohol in combination with illicit drugs among fatal injuries in Sao Paulo, Brazil: an epidemiological study on the association between acute substance use and injury. Injury. https://doi.org/10.1016/j.injury.2018.09.035

Andreuccetti, G., Leyton, V., Lemos, N. P., Miziara, I. D., Ye, Y., Takitane, J., \& de Carvalho, H. B. (2017). Alcohol use among fatally injured victims in São Paulo, Brazil: bridging the gap between research and health services in developing countries. Addiction, 112(4), 596-603. https://doi.org/10.1111/add.13688

Bakke, E., Bogstrand, S. T., Normann, P. T., Ekeberg, Ø., \& Bachs, L. (2016). Influence of alcohol and other substances of abuse at the time of injury among patients in a Norwegian emergency department. BMC Emergency Medicine, 16(1). https://doi.org/10.1186/s 12873-016-0085-2

Bastos, F. I. P. M., Vasconcellos, M. T. L., De Boni, R. B., Dos Reis, N. B., \& Coutinho, C. F. S. (Org.). (2017) III LNUD. Levantamento nacional sobre o uso de drogas pela população brasileira. Rio de Janeiro: ICICT/FIOCRUZ.

Brandão, G. C. G., Barrêto; A. J. R., Gaspar, J. C.; Trindade, R. F. C., Vaz, N. L. F., \& Oliveira, M. A. C. (2014). Accidents and violence: a portrait of the occurrences in emergency care services. Cadernos de Saúde Coletiva, 22(1), 2-7.

Brunton, L. L., Lazo, J.S., \& Parker, K. L. (2018). Goodman \& Gilman's: as bases farmacológicas da terapêutica. (13ª ed.) Rio de Janeiro: McGraw Hill.

Champion, H. R., Sacco, W. J., Carnazzo, A. J., Copes, W. S., \& Fouty, W. J. (1981). Trauma score. American journal of respiratory and critical care medicine 9, 672-676.

Damacena, G. N., Malta, D. C., Boccolini, C. S., Souza Júnior, P. R. B. de, Almeida, W. da S. de, Ribeiro, L. S., \& Szwarcwald, C. L. (2016). Consumo abusivo de álcool e envolvimento em acidentes de trânsito na população brasileira, 2013. Ciência \& Saúde Coletiva, 21(12), 37773786. https://doi.org/10.1590/1413-812320152112.25692015

Degenhardt, L., Mathers, B., Hall, W. D. Response to Hser et al. (2014): The necessity for more and better data on the global epidemiology of opioid dependence. Addiction Journal 109(8),1335-1337.

Di Marzo, V., Bifulco, M., \& Petrocellis, L. (2014). The Endocannabinoid System and its Therapeutic Exploitation. Nature Reviews Drug Discovery, 13, $771-784$.

Elvik, R. (2013). Risk of road accident associated with the use of drugs: a systematic review and meta-analysis of evidence from epidemiological studies. Accident Analysis \& Prevention, 60, 254-267. https://doi.org/10.1016/j.aap.2012.06.017

Gomes, A. T. L., Silva, M. F., Dantas, B. A. S., Dantas, R. A. N., Mendonça, A. E. O., \& Torres, G. V. (2016). Characterization of traffic accidents attended by a mobile urgency care service. Fundamental Care Online, 8(2), 4269-4279. 
Hartman, R. L., Brown, T. L., Milavetz, G., Spurgin, A., Pierce, R. S., Gorelick, D. A., Gaffney, G., \& Huestis, M. A. (2015). Cannabis effects on driving lateral control with and without alcohol. Drug and Alcohol Dependence, 154, 25- 37. https://doi.org/10.1016/j.drugalcdep.2015.06.015

Klaassen, C. D. (2018). Casarett \& Doull's Toxicology: The basic science of poisons. ( $9^{\text {th }}$ ed.) Mc-Graw-Hill Co.

Legrand, S. A., Silverans, P., De Paepe, P., Buylaert, W., \& Verstraete, A. G. (2013). Presence of psychoactive substances in injured Belgian drivers. Traffic Injury Prevention, 14(5), $461-8$.

Lasebikan, V. O.\& Adebayo, S. (2013). Need for screening for alcohol and drugs in emergency trauma units. East African Medical Journal, $90(5), 164$-70. Levine, B. (1999). Ethanol. In: Lasebikan, V. O. \& Adebayo, S. Principles of Forensic Toxicology. American Association for Clinical Chemistry, $170-184$.

National Institute on Drug Abuse. (2019). Drugged Driving Drug Facts. Retrieved from https://www.drugabuse.gov/publications/drugfacts/drugged-driving on 2021, March 7

Macinko, J. (2015). Avanços na vigilância da saúde pública brasileira. Ciência Saúde Coletiva, 20(3), 6286-9. https://doi.org/10.1590/141381232015203.20092014

Macinko, J., Mullachery, P., Silver, D., Jimenez, G., \& Libanio Morais Neto, O. (2015). Patterns of Alcohol Consumption and Related Behaviors in Brazil: Evidence from the 2013 National Health Survey (PNS 2013). PLOS ONE, 10(7), e0134153. https://doi.org/10.1371/journal.pone.0134153

Malta, D. C., Bernal, R. T. I., Mascarenhas, M. D. M., Silva, M. M. A., Szwarcwald, C. L., \& Morais Neto, O. L. de. (2015). Consumo de bebidas alcoólicas e direção de veículos nas capitais brasileiras e no Distrito Federal, segundo dois inquéritos nacionais de saúde. Revista Brasileira de Epidemiologia, 18(suppl 2), 214-223. https://doi.org/10.1590/1980-5497201500060019

Martins, C. B. G. (2013). Accidents and violence in childhood and adolescence: risk and protective factors. Revista Brasileira de Enfermagem, 66(4), 578-584.

Ministério da Saúde, Brasil. (2019). Guia de vigilância em saúde. (3a ed.) Brasília, DF.

Moreau, R. L. M., \& Siqueira, M. E. P. B. (2016). Ciências farmacêuticas: toxicologia analítica. (2. ed.) Rio de Janeiro: Guanabara Koogan.

Mundenga, M. M., Sawe, H. R., Runyon, M. S., Mwafongo, V. G., Mfinanga, J. A., \& Murray, B. L. (2019). The prevalence of alcohol and illicit drug use among injured patients presenting to the emergency department of a national hospital in Tanzania: a prospective cohort study. BMC Emergency Medicine, 19(1). https://doi.org/10.1186/s12873-019-0222-9

Okumura, Y., Shimizu, S., Ishikawa, K.B, Matsuda S, \& Fushimi K, Ito H. (2012). Comparison of emergency hospital admissions for drug poisoning and major diseases: a retrospective observational study using a nationwide administrative discharge database. BMJ Open, 2(6),1-6.

Oliveira, C. M., \& Cruz, M. M. (2015). Sistema de Vigilância em Saúde no Brasil: avanços e desafios. Saúde em Debate, 39(104), 255 267. https://doi.org/10.1590/0103-110420151040385

Organização Pan-Americana de Saúde. Trânsito: um olhar da saúde para o tema [Internet]. Brasília: OPAS; 2018 [acessado em 06 mar. 2021$]$. Disponível em: http:// iris.paho.org/xmlui/handle/123456789/49709

Parreira, J. G., Matar, M. R., Tôrres, A. L. B., Perlingeiro, J. A. G., Solda, S. C., \& Assef, J. C. (2014). Comparative analysis between identified injuries of victims of fall from height and other mechanisms of closed trauma. Revista Do Colégio Brasileiro de Cirurgiões, $41(4)$, 272-277. https://doi.org/10.1590/0100-69912014004009

Passagli, M. (2018). Toxicologia forense: teoria e prática. (5. ed.) Campinas, SP: Milenium.

Pereira, A. S., Shitsuka, D. M., Parreira, F. J. \& Shitsuka, R. (2018). Metodologia da Pesquisa Científica. Santa Maria, RS : UFSM, NTE.

Rutstein, D. D., Berenberg, W., Chalmers, T. C., Child, C. G., Fishman, A. P., \& Perrin, E. B. (1976). Measuring the quality of medical care: a clinical method. New England Journal of Medicine, 294(11), 582-588.

Santana, C. J., Silvino, M. C. S., Rosa, N. M., Almeida, E. G., Reis, L. M., \& Oliveira, M. L. F. (2014). Potencialidade de um evento sentinela para vigilância epidemiológica do abuso de drogas. Journal of Nursing UFPE Online, 8(12), 321-327.

Santana, C. J., Cristophoro, R., Ortiz, M. M., Santos, D. R., Reis, L. M., \& Oliveira, M. L. F. (2020) Análise de Causa Raiz em Internações por Drogas de Abuso como Eventos Sentinela. Revista de Enfermagem do Centro Oeste Mineiro, 10(e3542). http//doi.org/10.19175/recom.v10i0.3542

Silva, E. R., Ferreira, A. C. Z., Boraba, L. O., Kalinke, L. P., Nimtz, M. A., \& Maftum, M. A. (2016). Drug use impact in drug addicts' physical and mental health. Ciência Saúde Coletiva, 15(1), 101-108.

Souto, R. M. C. V., Corassa, R. B., Lima, C. M., \& Malta, D. C. (2017). Helmet use and injury severity among crashed motorcyclists in Brazilian state capitals: an analysis of the violence an accidents survey. Revista Brasileira de Epidemiologia, 23 (1),1-12. https://doi.org/10.1590/1980-549720200011.supl.1

Teasdale, G., \& Jennett, B. (1974). Assessment of coma and impaired consciousness: a practical scale. Lancet, 2, 81-84.

United Nations Office on Drugs and Crime (2019). World Drug Report Vienna

Waksman, R. D., \& Imamura, J. H. (2013). Aspectos Epidemiológicos e Prevenção Primária do Trauma. In: Adalberto Stape; Eduarod Juan Troster; Jaques Pinus; Renata Dejtiar Waksman; Renato Melli Carrera, Sulim Abramovici. (Org.). Roca, v.1, 07-13.

World Health Organization (2018a). Global status report on road safety 2018: supporting a decade of action. Geneva: WHO, 2018a https://www.who.int/violence_injury_prevention/road_safety_status/2018/en/. Acesso em fev. 2021. 
Research, Society and Development, v. 10, n. 4, e43010414273, 2021

(CC BY 4.0) | ISSN 2525-3409 | DOI: http://dx.doi.org/10.33448/rsd-v10i4.14273

World Health Organization. Global status report on alcohol and health, (2018b). https://apps.who.int/iris/bitstream/handle/10665/274603/9789241565639eng.pdf?ua=1. Acesso em fev. 2021. 